\title{
A ductile extensional shear zone at the contact area between HP-LT metamorphic units in the Talea Ori, central Crete, Greece: deformation during early stages of exhumation from peak metamorphic conditions
}

\author{
Lina Seybold ${ }^{1}$ (I) Claudia A. Trepmann ${ }^{1} \cdot$ Emilie Janots $^{1,2}$
}

Received: 7 August 2018 / Accepted: 20 September 2018 / Published online: 6 October 2018

(c) The Author(s) 2018

\begin{abstract}
We report on an extensional ductile shear zone in central Crete at the contact area between the high-pressure low-temperature (HP-LT) metamorphic Phyllite-Quartzite unit sensu stricto (PQ s.str.) and the Talea Ori group (Plattenkalk unit). Mapping and microscopic analysis along the $20 \mathrm{~km}$ long contact reveal extensional shear bands, shear band cleavages ( $\mathrm{C}^{\prime}$-type) and associated quartz veins in both units, occurring over a width of up to a kilometer. The shear offset along the shear bands is systematically perpendicular to the contact with the hanging block (PQ s.str.) being downfaulted. Abundant discordant quartz veins are associated to shear band boundaries, asymmetric boudinage and foliation boudinage, forming m-wide vein networks. These mesoscopic deformation structures together with related microstructures such as strain shadows, growth rims of albite porphyroblasts and stylolites indicate dissolution-precipitation creep as main deformation mechanism accompanied by vein formation. Temperatures during deformation are indicated to be close to peak metamorphic temperatures $\left(\geq 300-350{ }^{\circ} \mathrm{C}\right)$ by the growth rims of albite porphyroblasts and micas present in the shear band cleavages, which are consistent with quartz vein microstructures showing subgrains and sutured high angle grain boundaries. Peak metamorphic temperatures inferred by the degree of graphitization of carbonaceous material are similar in the hanging wall and the footwall of the shear zone, which is consistent with fast and nearly adiabatic exhumation. Our study demonstrates the importance of ductile shear zones with high strain rate dissolution-precipitation creep and vein formation in HP-LT metamorphic rocks for the early exhumation history.
\end{abstract}

Keywords Exhumation $\cdot$ Shear bands $\cdot$ Dissolution-precipitation creep $\cdot$ PQ s.str. $\cdot$ Plattenkalk $\cdot$ Albite

\section{Introduction}

In the Hellenic subduction system, the role of low-angle detachment faults and ductile shear zones on the exhumation of high-pressure low-temperature (HP-LT) metamorphic rocks is discussed controversially, regarding the amount of exhumation localized on these faults and their relation to crustal scale extension or syncompressional normal faulting

Electronic supplementary material The online version of this article (https://doi.org/10.1007/s00531-018-1650-6) contains supplementary material, which is available to authorized users.

Lina Seybold

lina.seybold@1mu.de

1 Ludwig-Maximilians-Universität, Luisenstraße 37, 80333 Munich, Germany

2 Univ. Grenoble Alpes, Univ. Savoie Mont Blanc, CNRS, IRD, IFSTTAR, ISTerre, 38000 Grenoble, France in extrusion wedges (e.g., Lister et al. 1984; Fassoulas et al. 1994; Kilias et al. 1994; Jolivet et al. 1996, 2013; Thomson et al. 1999; Doutsos et al. 2000; Ring and Reischmann 2002; Rahl et al. 2005; Chatzaras et al. 2006; Klein et al. 2008, 2013; Ring et al. 2010). In the model of syncompressional exhumation in an extrusion wedge, which was proposed e.g., for the Peloponnesus and the island of Crete, deformation is localized on two bounding faults and the extruded rocks are exhumed as one coherent block (Thomson et al. 1999; Doutsos et al. 2000; Ring and Reischmann 2002). In association to crustal scale extension, ductile extensional shear zones have been described on Crete also within the exhumed HP-LT metamorphic rocks (Fassoulas et al. 1994; Jolivet et al. 1996). On Crete, a low-angle normal fault, the so-called "Cretan detachment" is in both cases suggested to have played a major role for exhumation of the Miocene HP-LT metamorphic rocks. At the Cretan detachment a HP-LT metamorphic lower group of nappes is overlain by an upper group of nappes that do not show a comparable 
Miocene HP-LT metamorphism (Lister et al. 1984; Fassoulas et al. 1994; Kilias et al. 1994; Jolivet et al. 1996; Thomson et al. 1998; Ring and Reischmann 2002). The nappe situated directly above the detachment (the Tripolitza series), revealed, however, only slightly lower metamorphic peak temperatures than the underlying HP-LT metamorphic nappes (Feldhoff et al. 1991, 1993; Rahl et al. 2005; Klein et al. 2008, 2013). Based on the small temperature difference, Rahl et al. (2005) estimated that the detachment accounts for only $\sim 5$ to $7 \mathrm{~km}$ of exhumation of the underlying HP-LT metamorphic rocks from $\sim 35 \mathrm{~km}$ depths. The activation of more than one single detachment fault was suggested (Papanikolaou and Vassilakis 2010; Ring et al. 2010), which may also be located within the lower HP-LT metamorphic group and rather of ductile character (Klein et al. 2013).

In the Talea Ori, central Crete, the lowermost HP-LT metamorphic units of the Cretan nappe pile, the Talea Ori group (Plattenkalk unit), and the overlying PQ s.str. are exposed. There, siliciclastic rocks forming the base of the Talea Ori group, not known from other areas on Crete and the Peloponnesus, are in contact with the siliciclastic metasediments of the PQ s.str. This offers the unique possibility to evaluate the deformation at the contact between Talea Ori group and PQ s.str. within rocks of similar lithology and rheology. In the Talea Ori, that contact has been described as thrust fault related to early nappe stacking (Chatzaras et al. 2006; Xypolias et al. 2007), whereas other authors observed mainly normal faults (Richter and Kopp 1983). Rocks from the contact area show microstructures indicative of transient high stresses (few hundred of MPa) within metasediments deforming by dissolution-precipitation creep at high strain rates on long term (Trepmann and Seybold 2018). Such microstructures cannot be reconciled with low stress deformation at HP-LT metamorphic conditions in subduction zones as typically recorded from HP-LT metamorphic rocks in Western Crete (Greiling 1982; Schwarz and Stöckhert 1996; Stöckhert et al. 1999), but they document the early exhumation history of the HP-LT metamorphic rocks. In this study, we mapped the deformation structures of the contact area between the base of the Talea Ori group and the PQ s.str. in close relation to microfabric analysis. Based on our observations we discuss the deformation mechanisms and conditions with respect to the subduction and exhumation history of the HP-LT metamorphic rocks in the Talea Ori.

\section{Regional geology}

The Cretan nappe pile developed during northward subduction of oceanic crust and subsequent collision of the northern margin of a microcontinent, belonging to the African Plate, with the southern margin of the Eurasian Plate in Miocene times (e.g., Fassoulas et al. 1994; Kilias et al. 1994; Jolivet et al. 1996; Robertson et al. 1996; Thomson et al. 1999; ten Veen and Kleinspehn 2003; Meier et al. 2007; Ring et al. 2010). Parts of the sedimentary cover of the microcontinent were buried to HP-LT metamorphic conditions during collision and were rapidly exhumed during the Miocene (Thomson et al. 1998, 1999; Seidel et al. 2007; Ring et al. 2010).

The HP-LT metamorphic lower nappes of the Cretan nappe pile are well exposed in the Talea Ori, in the northern part of central Crete (Fig. 1). There, the Late Carboniferous/ Early Permian to Oligocene metasediments of the Talea Ori group, are tectonically overlain by the Phyllite-quartzite unit (e.g., Epting et al. 1972; Kuss and Thorbecke 1974; Creutzburg and Seidel 1975; Jacobshagen et al. 1978; König and Kuss 1980; Bonneau 1984; Jacobshagen et al. 1986; Kock et al. 2007; Robertson 2012; Zulauf et al. 2016). The Talea Ori group comprises characteristic platy marbles with cherts (Plattenkalk sensu stricto) at the top, which are correlated to other outcrops of similar Plattenkalk-chert associations on Crete and the Peloponnesus (Kuss and Thorbecke 1974; Jacobshagen et al. 1978; Soujon et al. 1998). A wide variety of names was used for this lowest nappe, including, e.g., Plattenkalk series, Ida-Zone, Talea Ori unit, Crete-ManiZone (Manutsoglu et al. 1995a and references therein; Kock et al. 2007). Since in the Talea Ori, the Plattenkalk s.str. is underlain by a siliciclastic/carbonatic succession, which is not known from any other occurrence on Crete or the Peloponnesus, we use the term "Talea Ori group", following the recommendation of Manutsoglu et al. (1995a).

The different formations of the Talea Ori group are stratigraphically from bottom to top (Fig. 1): the late Carboniferous to early Permian Bali beds (also referred to as "Galinos shale" by König and Kuss 1980), the early to late Permian lower and upper Fodele beds, the Triassic Sisses beds, the Norian to Liassic stromatolite dolomite marble and the Jurassic to Eocene Plattenkalk s.str. (Epting et al. 1972; König and Kuss 1980; Hall and Audley-Charles 1983; Krahl et al. 1988; Manutsoglu et al. 1995b; Kock et al. 2007). These formations are structurally overlain by phyllites, quartzites, albite- and chloritoid schists of the PQ s.str. (e.g., Creutzburg and Seidel 1975; Bonneau 1984).

All units in the Talea Ori experienced Alpine HP-LT conditions, as indicated by characteristic mineral assemblages (e.g., Mg-carpholite, sudoite, topaz, chloritoid, and lawsonite in the Sisses beds, and blue amphibole (crossite) in the metavolcanic rocks NW of Fodele, Seidel 1978; Seidel et al. 1982; Theye 1988; Theye and Seidel 1991; Theye et al. 1992). From these studies, the metamorphic conditions were estimated around $\sim 0.9 \mathrm{GPa}$ and $350{ }^{\circ} \mathrm{C}$, converting in $\sim 30 \mathrm{~km}$ deep subduction. The temperature constraints are consistent with the degree of graphitization of carbonaceous material for central Crete, indicating temperatures around $400{ }^{\circ} \mathrm{C}$ (Rahl et al. 2005). 

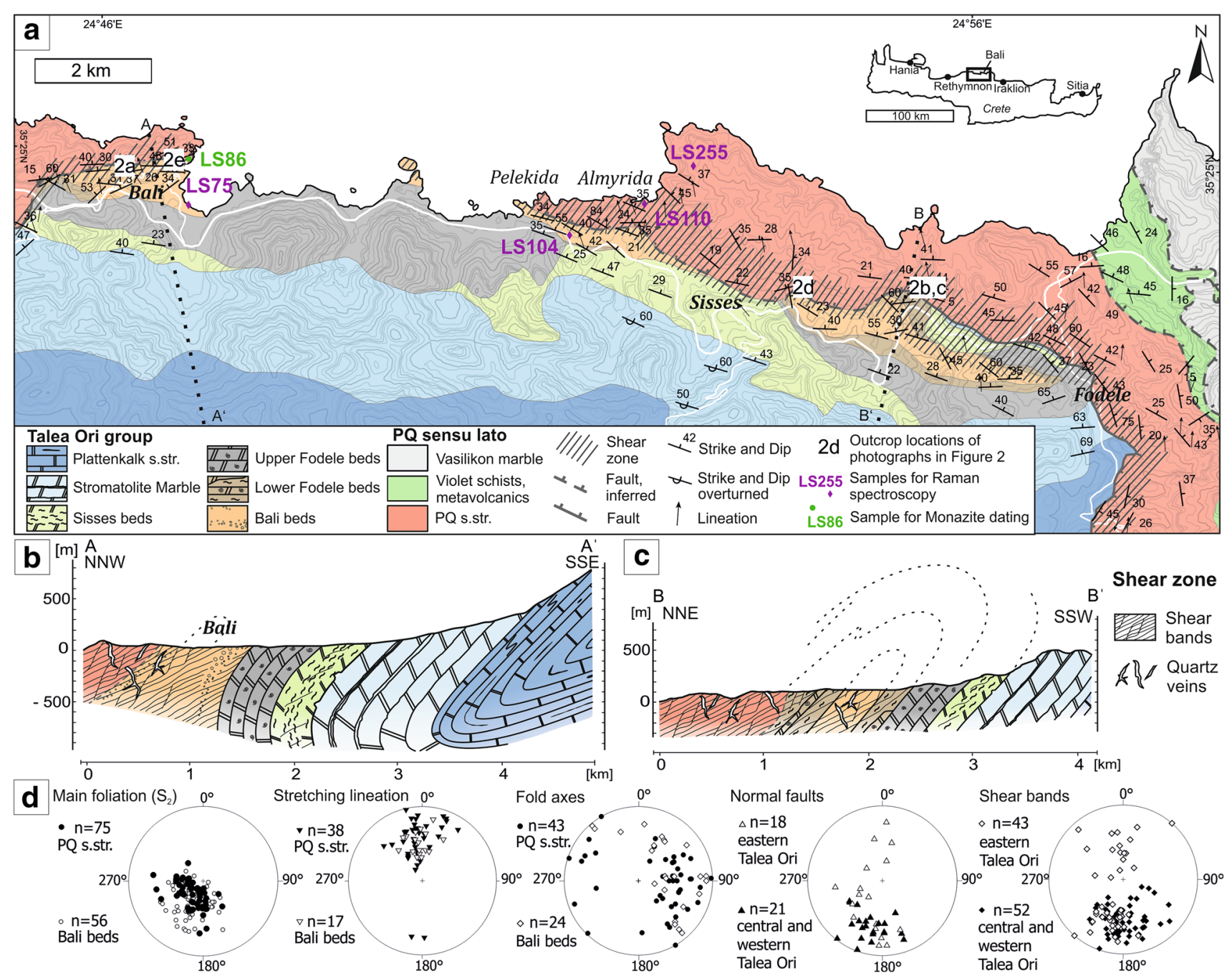

Fig. 1 a Geologic map of the Talea Ori modified after Epting et al. (1972), Richter and Kopp (1983) and Kock et al. (2007). The dashed area marks the position of the extensional shear zone. b Profile along

line $\mathrm{AA}^{\prime}$, modified after Kock et al. (2007) and $\mathbf{c}$ along line $\mathrm{BB}^{\prime}$, after Richter and Kopp (1983) as marked in the map. d Stereographic projections, lower hemisphere, of deformation structures

The main part of the Talea Ori group is structurally inverted, forming an overturned limb of a large-scale south-vergent fold structure with eastward plunging fold axis (Fig. 1; Epting et al. 1972; König and Kuss 1980; Richter and Kopp 1983; Krahl et al. 1988; Chatzaras et al. 2006; Kock et al. 2007). Due to the overturned fold structure of the Talea Ori group, its siliciclastic base is in contact to the PQ s.str. in the central and western Talea Ori (Fig. 1). In the eastern Talea Ori, the strongly deformed and thinned non-inverted limb of the large-scale fold structure is marking the contact of higher formations of the Talea Ori group to the PQ s.str. (Fig. 1; "Schubfetzenzone" sensu Epting et al. 1972; Richter and Kopp 1983). Because of the high strain and the similar lithology of the siliciclastic metasediments from the Talea Ori group and the PQ s.str. at their contact, there is quite a large variability in the reported position of the contact in existing maps, especially in the western Talea Ori (Epting et al. 1972; König and Kuss 1980; Richter and Kopp 1983; Kock et al. 2007).

For both the Talea Ori group and the PQ s.str. a common tectonic history has been described with a first deformation event represented by fold axes trending N-S to E-W (Krahl et al. 1988; Chatzaras et al. 2006; Zulauf et al. 2016; Fig. 1). Chatzaras et al. (2006) related south-vergent fold axes that are $\mathrm{E}-\mathrm{W}$ trending and top-to-the-south shear senses to the overthrusting of the PQ s.str. onto the Talea Ori group. The early deformation is recorded by internal fabrics in albite and by isoclinal folding of a bedding-parallel first foliation (Krahl et al. 1988; Chatzaras et al. 2006; Zulauf et al. 2016). The dominant foliation is related to a second deformation event with top-to-the-north shear sense at HP-LT metamorphic conditions (Zulauf et al. 2016). Zulauf et al. (2016) distinguished a third deformation phase associated with 
north-vergent E-W trending fold axes after peak metamorphic conditions at higher structural levels.

\section{Methods}

During field campaigns between 2015 and 2017 lithological and structural mapping of the $20 \mathrm{~km}$ long contact area between the base of the Talea Ori group and PQ s.str. was carried out. About 300 samples were collected and analysed microscopically to thoroughly distinguish between the deformed HP-LT metasediments of the two units as well as to distinguish between deformation related to the main fabric formed at peak metamorphic conditions and the ductile shear zone. For geographic coordinates of the samples shown here, refer to Table 1 in the supplementary data. For structural analysis, the samples were taken oriented in the field. Polished thin sections (with approximately $25 \mu \mathrm{m}$ thickness) were prepared from cuts oriented parallel to the lineation and perpendicular to the foliation. The microfabrics were analyzed by polarized light microscopy and scanning electron microscopy (SEM), including electron backscattered diffraction (EBSD) measurements and energy dispersive spectroscopy (EDS) using a field emission microscope (SU5000 Hitachi) at Ludwig-Maximilians University, Munich, Department of Earth and Environmental Sciences. The sections for EBSD measurements were polished by an alkaloid colloidal suspension (Syton) prior to carbon coating. EDS and EBSD signals were acquired using the Aztec software (Oxford technology). For EDS measurements a working distance of $10 \mathrm{~mm}$ and for EBSD a working distance of 20-25 mm was applied at an acceleration voltage of $20 \mathrm{kV}$. For EBSD measurements we used a pre-tilted holder with the specimen at an angle of $70^{\circ}$ to the beam. Processing of the data was performed with the Channel 5 software (Oxford technology). Grain size is given as the diameter of a circle of equal area applying a misorientation threshold value of $10^{\circ}$. Crystallographic orientations are presented by stereographic projections of the lower hemisphere.

Raman spectroscopical investigations on carbonaceous material $(\mathrm{CM})$ were made on polished petrographic thin sections, using a Horiba Xplora integrated confocal micro Raman system on an Olympus BX51 microscope (Mineralogical state collection, Munich). For the measurements a Nd-YAG $532 \mathrm{~nm}$ laser source was used and the laser was focused on the sample with a $300 \mathrm{~nm}$ confocal hole. Laser power on the sample surface was $8.4 \mathrm{~mW}$. The laser was focused, using a $100 \times \mathrm{LW}$ objective (with larger working distance), on spots of CM below the surface beneath translucent grains as quartz, to avoid bias due to polishing of the sample surface. 10 to 12 spots were measured per sample with an acquisition time of $5 \mathrm{~s}$. Background correction and peak fitting of the $\mathrm{G}$ band $\left(1580 \mathrm{~cm}^{-1}\right), \mathrm{D} 1$ band $\left(1350 \mathrm{~cm}^{-1}\right)$ and $\mathrm{D} 2$ band $\left(1620 \mathrm{~cm}^{-1}\right)$ was performed using the software Peakfit (Version 4.06). Since we used a similar setting for the measurements as Rahl et al. (2005) temperatures were calculated by their equation using $\mathrm{R} 1$, which is the ratio of peak heights (D1/G), and R2, the ratio of peak areas $(\mathrm{D} 1 /(\mathrm{G}+\mathrm{D} 1+\mathrm{D} 2))$. By this method, metamorphic peak temperatures can be predicted to $\pm 50{ }^{\circ} \mathrm{C}$ (Rahl et al. 2005). A comparison with temperatures calculated using only R2 after Beyssac et al. (2002), showed no significant differences for the four samples measured (Table 2 in supplementary data). The standard deviation of the obtained temperatures from 10 measurements per sample was generally higher using the equation by Rahl et al. (2005), than using the equation of Beyssac et al. (2002).

For chemical in situ U-Th-Pb chemical dating, monazite grains were first identified on thin sections using backscatter electron (BSE) images by SEM. Quantitative analyses were acquired on a Jeol JXA-8230 at ISTerre laboratory (Grenoble, France). The analytical conditions follow a slightly modified protocol of Janots et al. (2008), with a beam diameter of $1 \mu \mathrm{m}$, an accelerating voltage of $15 \mathrm{kV}$ and a beam current of $200 \mathrm{nA}$. Natural minerals and synthetic glass standards, including Smithsonian REE phosphates, were used for calibration, with the following X-ray lines: $\operatorname{SiK} \alpha$, $\mathrm{UM} \beta$, ThM $\alpha, \operatorname{CaK} \alpha, \operatorname{PK} \alpha, \mathrm{YL} \alpha, \operatorname{DyL} \beta, \operatorname{GdL} \beta, \operatorname{SmL} \beta, \operatorname{PrL} \beta$, $\mathrm{NdL} \alpha, \operatorname{CeL} \alpha, \operatorname{LaL} \alpha, \operatorname{PbM} \beta$. Counting times of 80 (40), 150 (75) and 240 (120) were used for Th, U and $\mathrm{Pb}$ on peak and background, respectively. A calibrated overlap correction of 0.0079 was applied for peak interference of ThM $\gamma$ on UM $\beta$. Standardization and age calculations were checked before and after the analysis session using the Manangotry monazite standard (555 $\pm 2 \mathrm{Ma}$, ID-TIMS; Paquette and Tiepolo 2007). All analysed monazite grains have a $\mathrm{Pb}$ content below the detection limit $(<100 \mathrm{ppm}$, Table 3 in supplementary data).

\section{Results}

The contact between the Talea Ori group and the PQ s.str. is characterized by shear bands, extensional shear band cleavages, kink bands, asymmetric boudinage and a high amount of quartz veins that are associated to these structures (Figs. 2, 3 ). The abundance of these deformation structures increases within the Talea Ori group towards the contact to the PQ s.str., where the deformation structures occur over a width of up to $\sim 1 \mathrm{~km}$, along the $\sim 20 \mathrm{~km}$ long contact between the two units (dashed area in Fig. 1). In the following, we firstly describe the mesoscopic deformation structures that characterize the shear zone in the field and subsequently the microfabrics. To distinguish between deformation related to the ductile shear zone and the deformation at peak metamorphic conditions, we describe the relation between porphyroblast growth, foliation 

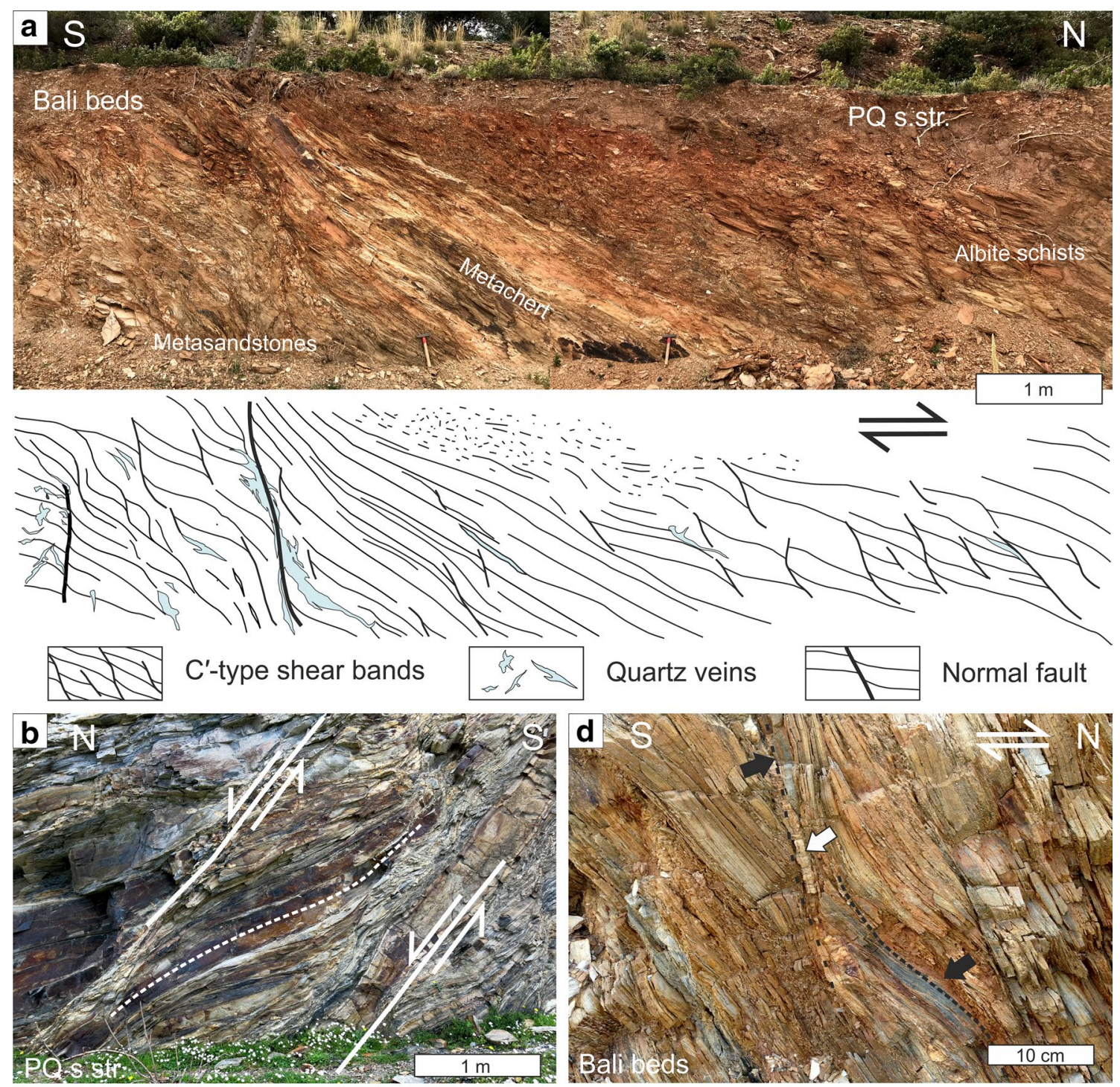

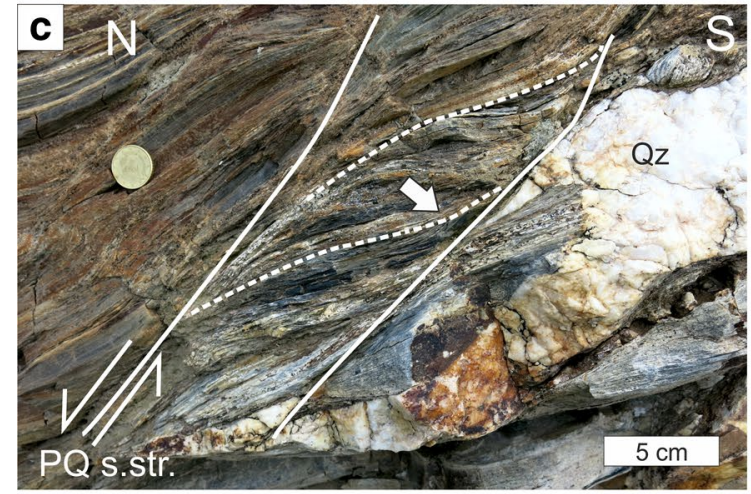

Fig. 2 Mesoscopic shear band cleavages at the contact between the base of the Talea Ori group and PQ s.str., locations of photograph within the shear zone are indicated in Fig. 1. a Shear zone at the contact between Bali beds (Talea Ori group) and PQ s.str. west of the village of Bali; the ductile shear bands are overprinted by brittle normal faults. b Shear bands in phyllites and quartzites of the PQ s.str. at Pera Galinos. c Shear bands and associated quartz vein in phyllites



of the PQ s.str. at Pera Galinos. d Shear band in schists interlayered with black chert, Bali beds east of Sisses; the black chert layer (black arrows) marks the top-down-to-the-north shear sense at the shear band. Quartz veins along the shear band boundary are indicated by white arrow. e Shear band in black schists of the Bali beds with associated quartz vein network, Bali port 

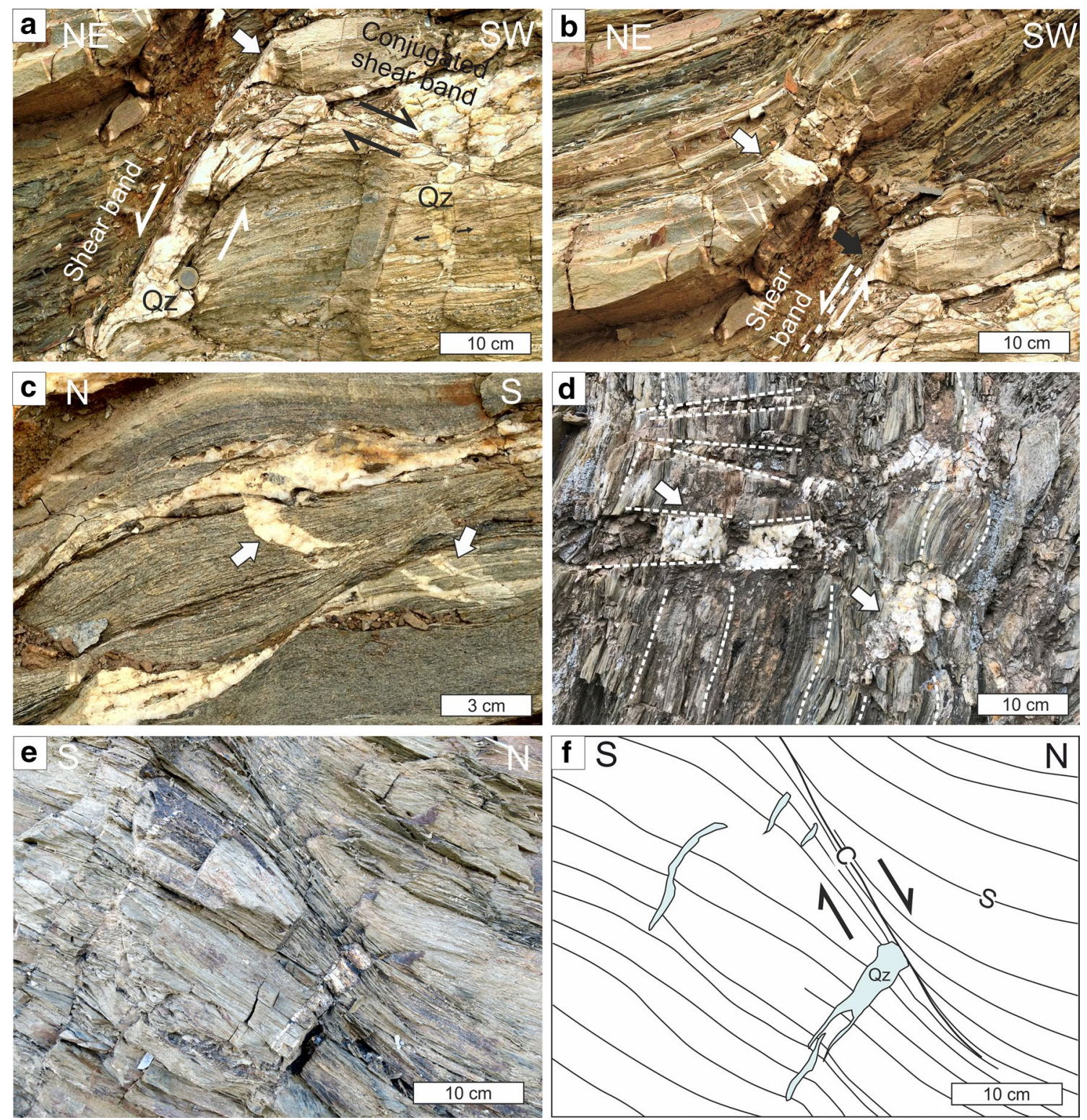

Fig. 3 Quartz veins associated to deformation structures of the extensional shear zone. a Quartz vein in asymmetric boudin neck of quartzite boudin (white arrow) along a shear band boundary with topdown-to-the-north shear sense; conjugated shear band with small displacement; quartz vein associated to foliation boudinage (tiny black arrows). b Asymmetric boudinage with quartz veins in boudin neck

and wedge-shaped veins. c Wing-shaped quartz veins associated to boudinage and shearing of phyllitic host rocks. d Foliation boudinage (white arrow) and quartz veins along kink band boundaries (dashed horizontal lines) e, f Shear band with branching quartz veins formed perpendicular to foliation

and shear band formation. The degree of graphitization of carbonaceous material in the hanging wall (PQ s.str.) and footwall (Talea Ori group) of the shear zone is analyzed to infer peak metamorphic temperatures.

\section{Macroscopic deformation structures of the shear zone}

In the western and central Talea Ori, the main foliation of the rocks, in the Talea Ori group and the PQ s.str., dips 
generally towards N (Fig. 1; Epting et al. 1972; König and Kuss 1980; Richter and Kopp 1983; Krahl et al. 1988). In the east, where the shear zone contact between Talea Ori group and PQ s.str. crosscuts the large-scale fold structure of the Talea Ori group, the foliation in the Talea Ori group is steadily $\mathrm{N}$-dipping, whereas the siliciclastic metasediments of the PQ s.str., are dipping towards $\mathrm{E}$ and SE, following the strike of the contact (Fig. 1a).

The shear zone is macroscopically characterized mainly by the occurrence of extensional shear bands, where the foliation is transected and deflected at the shear band boundaries (Figs. 2, 3). The shear band boundaries show a spacing on the scale of several centimeters to meters, and are commonly associated with quartz veins (Figs. 2, 3). In the western and central Talea Ori, exclusively one set of extensional shear bands occurs, with shear band boundaries dipping typically with $40-70^{\circ}$ towards $\mathrm{N}$ (perpendicular to the contact between Talea Ori group and PQ s.str.), with the northern block being systematically downfaulted (Figs. 1d, 2). In contrast, in the eastern Talea Ori, where the contact to the PQ s.str. is dipping to the $\mathrm{E}$ and $\mathrm{SE}$, also conjugated sets of shear bands occur (Figs. 1d, 3a).

In the shear zone, quartz veins discordant to the foliation form m-wide networks (Figs. 2a, c, e, 3). The quartz veins commonly occur along boundaries of mesoscopic shear bands (Figs. 2c, d, 3a), in the necks of (asymmetric) boudins (Fig. 3b, c) and in the necks of foliation boudinage (Fig. 3d-f; Platt and Vissers 1980; Birtel and Stöckhert 2008). Small (cm-wide) wedge-shaped and wing-shaped veins occur associated to the boudin necks or shear band boundaries (Fig. 3c). Shear bands and quartz veins are systematically more abundant in the Talea Ori group towards the contact to the PQ s.str., whereas they are rare within the central part of the Talea Ori. Brittle normal faults occur with similar strike and dip like the ductile shear bands (Figs. 1d, 2a), locally overprinting the shear band boundaries.

\section{Microstructures}

The mesoscopic shear bands are related to shear band cleavages (Fig. 4a-d), which are of C'-type, also referred to as extensional crenulation cleavage (Platt and Vissers 1980; Passchier and Trouw 2005; Mukherjee 2013a, 2014a). The shear band cleavages have typical spacings on the order of a few hundred $\mu \mathrm{m}$ to $\mathrm{mm}$, dependent on the grain size of the rocks (Fig. $4 \mathrm{a}$, b). The cleavage planes are defined by a relative enrichment of mica and opaque minerals, whereas quartz has been dissolved (Fig. $4 \mathrm{a}, \mathrm{b}$ ). The cleavage planes are at an angle of $30^{\circ}-60^{\circ}$ to the main foliation. Quartz precipitated at sites of dilation such as strain shadows and veins (Figs. 4b, c, 5, 6). Antitaxial strain shadows are developed usually around hematite crystals that are pseudomorphs after pyrite (Lougheed and Mancuso 1973) containing elongate quartz grains (late precipitates) and white mica (early precipitates, Fig. 4b). In strain shadows around albite porphyroblasts, quartz and albite are present (Fig. 5a). In albite gneisses, sutured passively enriched stylolytic seams of opaque phases occur along shear band boundaries (Fig. 4d).

Albite porphyroblasts occur frequently in the metasediments of the PQ s.str. (Figs. 4d, f, 5) and more rarely also in the Bali and Sisses beds of the Talea Ori group (Fig. 4e). These porphyroblasts typically show a high amount of mineral inclusions in the center, leading to a macroscopically black colour of albite, and an inclusion-free rim (Fig. 4e, f). They have anhedral elongated shapes, strain caps and (asymmetric) strain shadows forming a SPO parallel to the main foliation (Figs. 4f, 5). The albite blasts do neither show any compositional zoning nor internal misorientations (Fig. 5a).

The inclusions in albite porphyroblasts mainly comprise quartz, graphite, rutile and Fe-oxides. Tourmaline, calcite, ankerite, phengite, apatite, zircons, monazite, and allanite can also occur depending on the mineralogy of the host rock (Figs. 5a, b, 7). The small prismatic to ellipsoidal inclusions with sizes of a few $\mu \mathrm{m}$ up to $\sim 40 \mu \mathrm{m}$ are aligned with their long axis, forming an internal fabric $\left(\mathrm{S}_{1}\right)$. The internal fabric can be subparallel to the external foliation of the host rock $\left(\mathrm{S}_{2}\right)$, representing a former foliation which was overgrown by the albite blast $\left(\mathrm{S}_{1}\right.$, Figs. $\left.4 \mathrm{e}, \mathrm{f}, 5\right)$. In most albite-schists, the internal foliation is curved and oblique to the external foliation.

In general, quartz and albite in the rocks do not show a crystallographic preferred orientation (CPO), neither in the external foliation of the rocks nor in the inclusions or in the strain shadows (Fig. $5 \mathrm{c}-\mathrm{f}$ ). In the young quartz veins discordant to the foliation (Fig. 6a), as well as in monophase quartz layers concordant to the foliation (Fig. 6b), crystal-plastic deformation is evident by undulatory extinction, deformation lamellae and sutured grain boundaries (Fig. 6c) occurring in the Talea Ori group and the PQ s.str. (Trepmann and Seybold 2018).

Monazite crystals occur as inclusions in albite and ilmenite, as well as in the matrix of albite schists (Fig. 7a). The crystals are elongate parallel to the foliation (Fig. 7a). Monazite shows the same inclusions as albite blasts and is interpreted to have grown at the same time (Fig. 7). Monazite is zoned in light rare earth elements (Table 3 in supplementary data): a Nd-rich core (with $\mathrm{La} / \mathrm{Nd}$ as low as 0.4 ) is surrounded by a La-rich rim (with $\mathrm{La} / \mathrm{Nd}$ up to 1.3 ). The low $\mathrm{Pb}$ contents (below EMP detection limit $<100 \mathrm{ppm}$ ) of monazite with Th up to 5-7 wt.\% show that monazite crystallization age is younger than $60-80 \mathrm{Ma}$.

\section{Peak metamorphic temperatures of footwall and hanging wall of the shear zone}

The degree of graphitization of carbonaceous material, analyzed by Raman spectroscopy, depends on the peak 

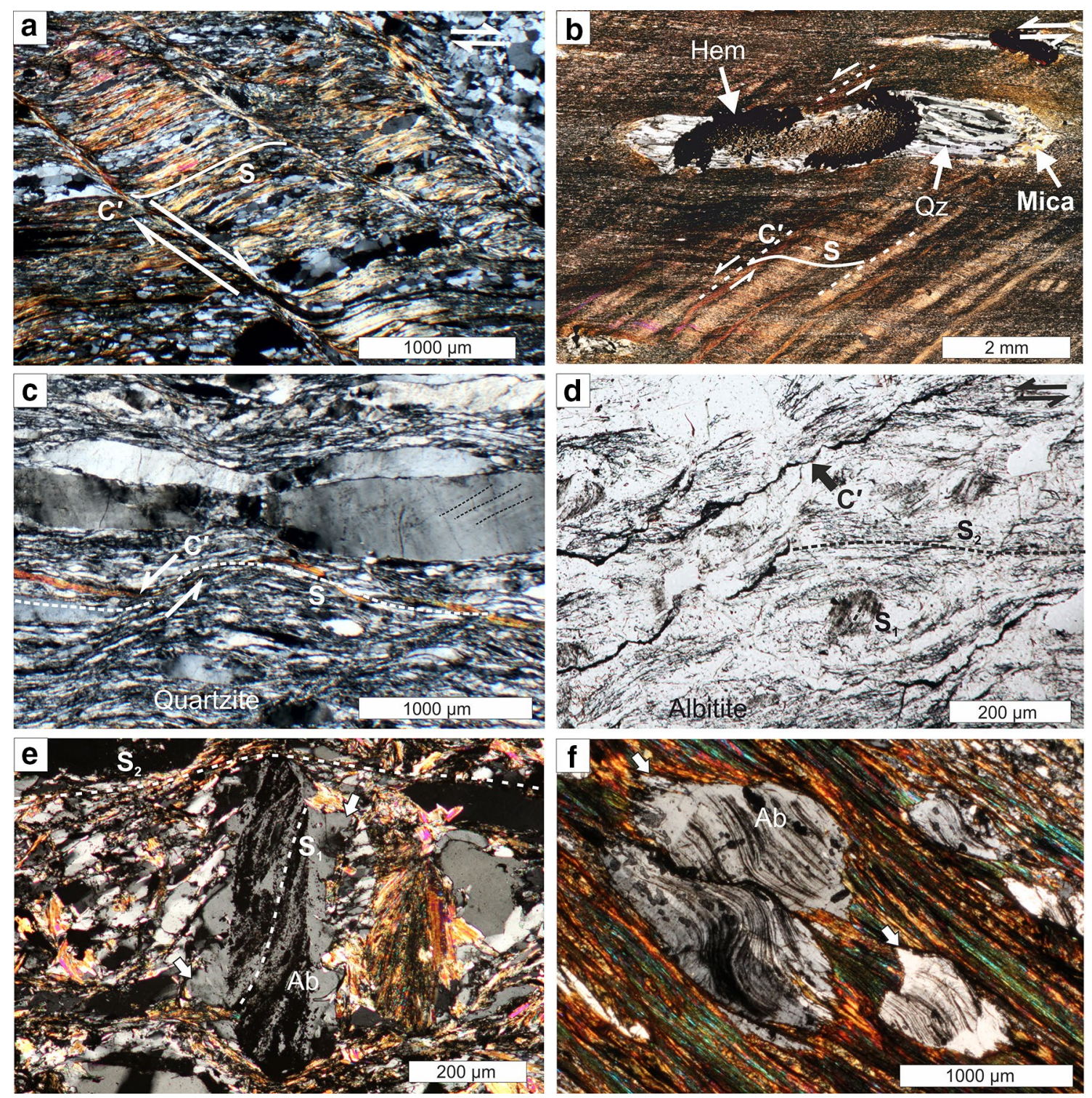

Fig. 4 Thin section micrographs of deformation structures in the Bali beds (Talea Ori group, a, b, e) and the PQ s.str. (c, d, f). a C'-type shear band cleavage in phyllites (CT83). b Antitaxial strain shadow around hematite pseudomorphs after pyrite and $\mathrm{C}^{\prime}$-type shear band cleavage in black schist (LS22). Shear sense is derived from shear band cleavage, since pressure fringes are symmetric. Stretching of hematite aggregate is consistent with sinistral shear sense. c $\mathrm{C}^{\prime}$-type shear bands in quartzite with deformation lamellae in deformed quartz grains and discordant quartz vein (LS48). d Albitite (LS51)

metamorphic temperatures (Beyssac et al. 2002). To distinguish the thermal peak recorded by the Talea Ori group in the footwall and the PQ s.str. in the hanging wall, Raman spectroscopy was carried out on four samples close to the contact of the two units (Fig. 1). From the Bali beds a black metachert (LS75) and a black shale (LS104) and from the PQ s.str. a fine grained dark quartzite (LS110) and an albite schist (LS255) were measured. On each of with stylolites marked by enrichment of opaque phases along shear band boundaries $\left(\mathrm{C}^{\prime}\right)$; albite grains have a high amount of opaque inclusions in the core that are aligned $\left(\mathrm{S}_{1}\right)$ oblique to the external foliation of the rocks $\left(\mathrm{S}_{2}\right)$. e Albite blast in metasandstone of the Bali beds (LS46). The internal foliation and long axis of the blast is perpendicular to the external foliation of the conglomerate $\left(S_{2}\right)$, the inclusion-free rim bulges in the direction of $S_{2}$. $\mathbf{f}$ Albite schist of the PQ s.str. (LS148) with curved internal foliation in albite grains and inclusion free rims, bulging into the external foliation

the four samples, several measurements of $\mathrm{CM}$ were collected in at least ten different spots, to get ten reliable Raman spectra per sample, which were analyzed to calculate temperatures. For each sample, from these ten calculated temperatures, the mean temperature and standard deviation were determined. For comparison, temperatures were determined after Rahl et al. (2005) as well as after Beyssac et al. (2002). Following the procedure of Rahl 




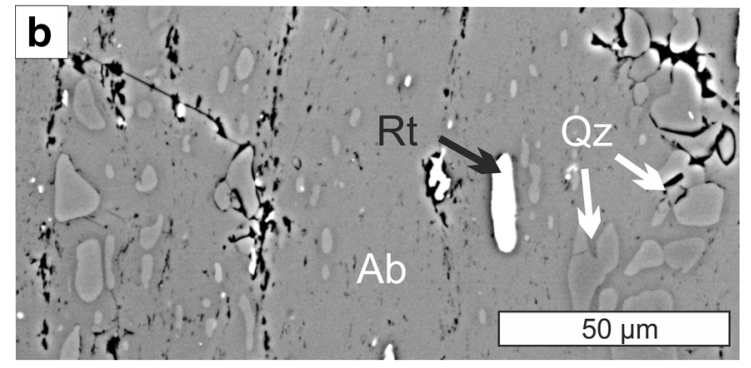


(010)
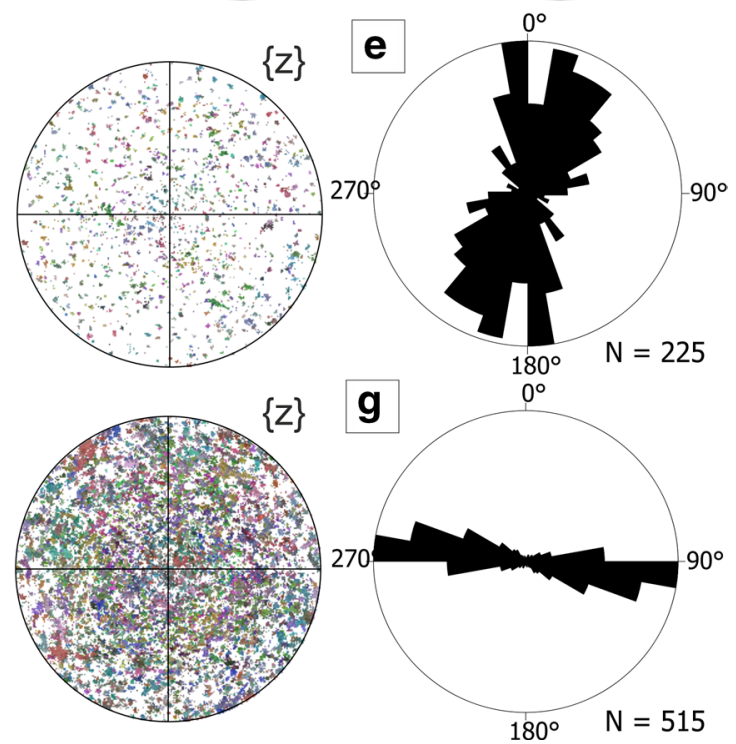

Fig. 5 a EBSD map of albite and quartz with internal foliation $\left(\mathrm{S}_{1}\right)$ oblique to the external foliation $\left(\mathrm{S}_{2}\right)$ of the schist (LS116, stepsize $0.6 \mu \mathrm{m})$. Colour coding of quartz by all Euler angles, large albite grain is coloured by relative misorientation with respect to blue orientation (blue to red $10^{\circ}$ misorientation angle). Note also isolated albite grains in the strain shadow (white arrows). b BSE-image of aligned

et al. (2005), for the Bali beds mean temperatures of $382{ }^{\circ} \mathrm{C}$ (LS104) and $403{ }^{\circ} \mathrm{C}$ (LS75) were obtained, and for the PQ s.str. $404{ }^{\circ} \mathrm{C}$ (LS110) and $408{ }^{\circ} \mathrm{C}$ (LS255). Calculation of the mean temperatures after Beyssac et al. (2002) showed a lower standard deviation within the

inclusion of rutile and quartz in albite. $\mathbf{c}$ Stereographic projections of poles to (100), (010), (001) of albite. d, f Stereographic projections of $c$ - and $a$ - axes and of the $\{\mathrm{r}\}$ and $\{\mathrm{z}\}$ planes of quartz in albite forming the internal fabric and in the matrix, respectively. e, g 2-D orientation of azimuth of long axis of quartz inclusions and quartz in the matrix, respectively

10 measurements per sample, with mean temperatures of $374{ }^{\circ} \mathrm{C}$ (LS104) and $397{ }^{\circ} \mathrm{C}$ (LS75) of the Bali beds and $381{ }^{\circ} \mathrm{C}$ (LS110) and $400{ }^{\circ} \mathrm{C}$ (LS255) of the PQ s.str. (Table 2 in supplementary data). 


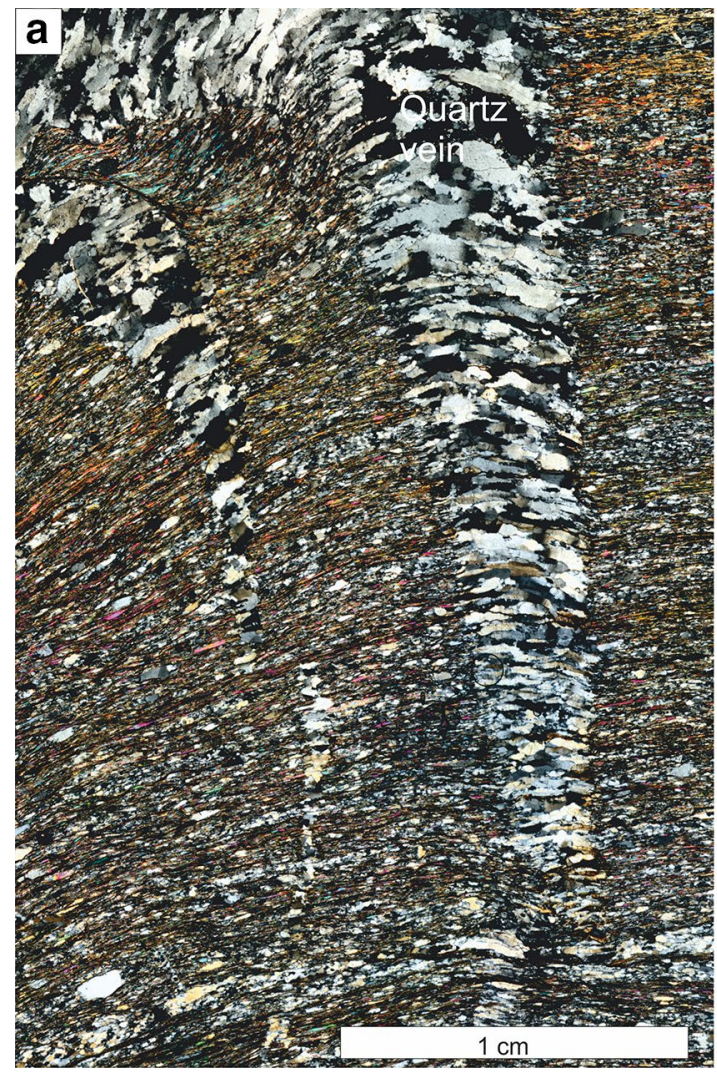

Fig. 6 Thin section scan (a) and photomicrographs (b, c) of quartz microstructures in the shear zone, crossed polarizers. a Wedgeshaped quartz vein discordant to the foliation in metasandstone (MS1). b Deformed quartz pebble in metaconglomerate (CT83). c

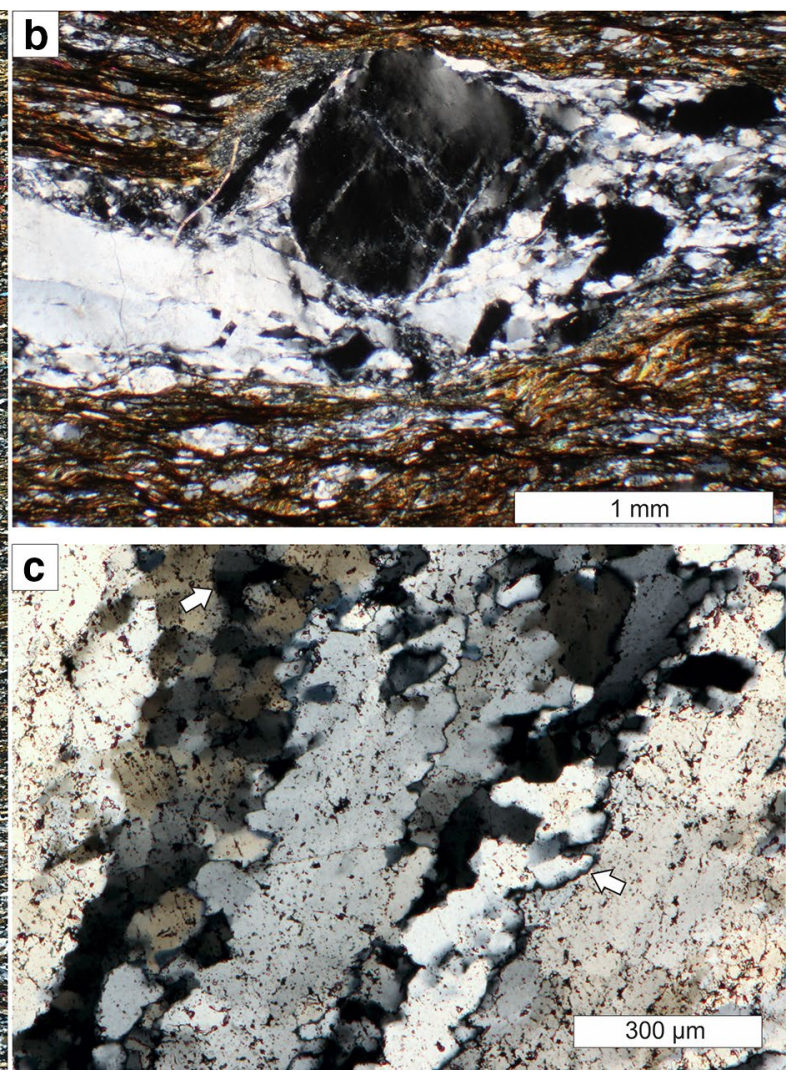

Sutured grain boundaries and subgrains indicating crystal-plastic deformation of quartz in quartz ribbons of wedge-shaped quartz vein (PM4)



Fig. 7 BSE micrographs of monazite grains in albite schist (LS86). a Monazite grains (white arrows) as inclusions in poikiloblasts of ilmenite/Fe-oxide and albite and in the mica-rich matrix. b Monazite

\section{Discussions}

In the following, we discuss the deformation, related to the formation of the extensional shear zone, and the

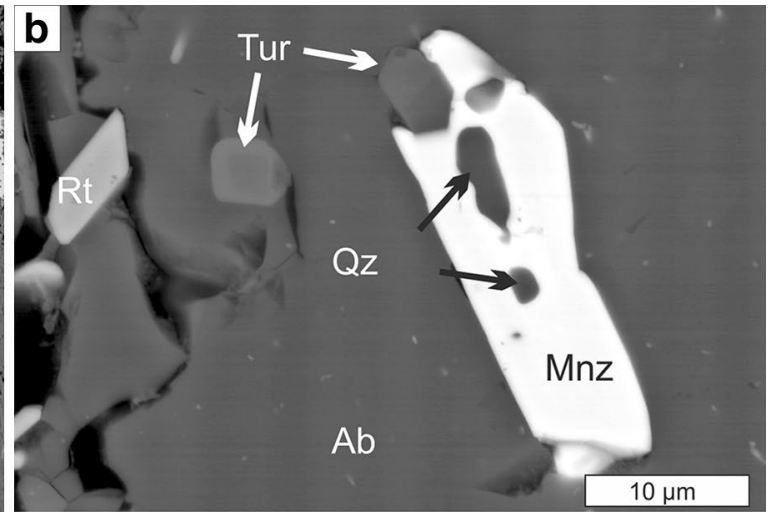

inclusion in albite, which itself has similar quartz inclusions. Mineral abbreviations used after Whitney and Evans (2010)

tectonometamorphic history of the Talea Ori group and the PQ s.str. 

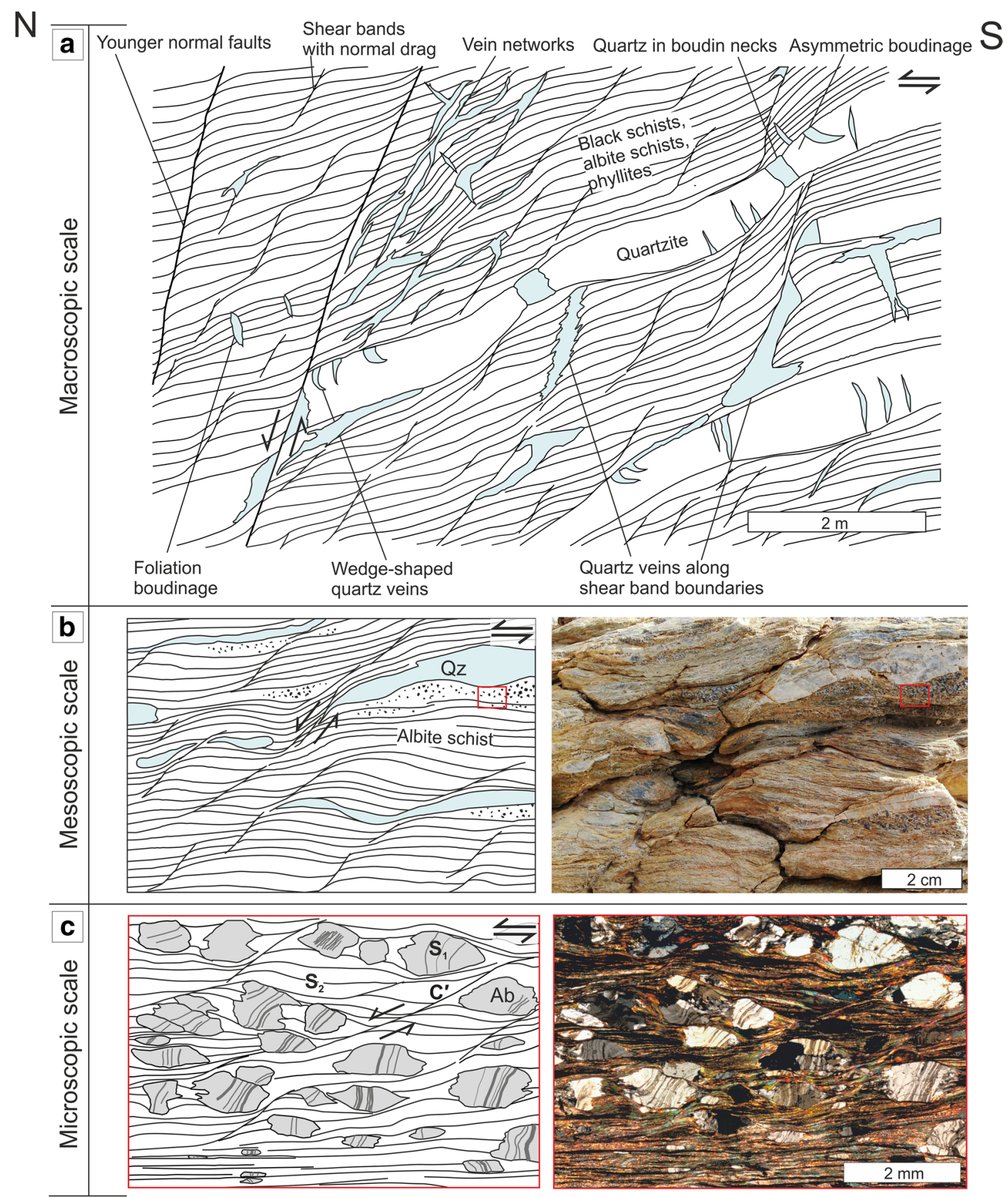

Fig. 8 Synoptic sketch of deformation structures in the extensional shear zone linking macroscopic, mesoscopic and microscopic scales. a Macroscopic view on deformation structures on outcrop scale. b Mesoscopic view on shear band cleavage on cm-scale in albite schist.

\section{The extensional shear zone}

The shear bands with associated quartz veins and shear band cleavages that characterize the shear zone, are summarized in a synoptic sketch, showing that on macro- to microscopic scale the hanging block is systematically downfaulted at c Microscopic view on same albite schist (red rectangle), showing $S_{1}$ (internal foliation in albite) and $\mathrm{S}_{2}$ (main foliation of the schist) overprinted by $\mathrm{C}^{\prime}$-type shear band cleavage (LS238). Several of the albite blasts show symmetric shape (Mukherjee 2017)

shear bands and shear band cleavages (Fig. 8). In the western and central Talea Ori, where the contact of the Talea Ori group to the PQ s.str. is striking $\mathrm{W}-\mathrm{E}$, the movement is consistent with a top-to-the-north shear sense. In the eastern Talea Ori, where the contact strikes N-S and cuts the fold structure of the Talea Ori group, conjugate sets of 
extensional shear bands occur. The occurrence of both simple and conjugate shear bands dependent on the strike of the shear zone indicates combinations of coaxial and noncoaxial deformation (Mukherjee 2013b). The extensional character of the shear zone is evident by the shear bands, with boundaries inclined at about $40^{\circ}-70^{\circ}$ and normal drag (Figs. 2, 8), the frequent quartz veins formed at dilational sites parallel to the shear band boundaries (Figs. 2c-e, 3a, 8 ), asymmetric boudinage with quartz filled boudin necks (Figs. 3b-f, 8) as well as shear band cleavages on microscopic scale (Figs. 4, 8). No indication of any substantial later rotation is present. Younger brittle normal faults overprint the ductile deformation structures (Figs. 1f, 2a, 8).

The main deformation mechanism forming the shear bands and shear band cleavages was dissolution-precipitation creep, as indicated by the relative enrichment of mica and opaque minerals in $\mathrm{C}^{\prime}$-type shear band cleavage planes (Fig. 4a, b), by quartz and albite precipitated in asymmetric strain shadows (Fig. 5) and in veins, by albite growth rims bulging parallel to the foliation (Figs. 4e, f, 5a, 8) and by stylolites in albitites (Fig. 4d). The albite growth rims show that the metamorphic conditions did not markedly differ during the onset of shear band formation with respect to the main foliation development. EBSD maps show that there is no CPO of quartz, as well as no internal deformation of albite (Fig. 5a), which indicates that crystal-plastic deformation did not play a major role for accumulating the main strain at any stage. Yet, monophase quartz layers parallel to the foliation as well as younger quartz veins discordant to the foliation related to the extensional shear bands, show microfabrics that indicate deformation by dislocation creep at temperatures of at least $300-350{ }^{\circ} \mathrm{C}$ (Trepmann and Seybold 2018). This indicates firstly that the extensional shear zone at the contact between Talea Ori group and PQ s.str. was activated at almost peak metamorphic conditions (consistent with the microfabrics in the metasediments) and secondly, that stresses were only locally and transiently high enough to cause crystal-plastic deformation.

The importance of dissolution-precipitation creep at peak metamorphic conditions has been reported for the PQ s.str. in Western Crete (e.g., Greiling 1982; Fassoulas et al. 1994; Schwarz and Stöckhert 1996; Stöckhert et al. 1999). Deformation related to the shear zone, however, is not pervasive and continuous. Instead, strain is localized within the shear zone forming shear bands. The abundant associated quartz veins discordant to the foliation and in association to the shear bands (Figs. 3, 6, 8) were interpreted by Trepmann and Seybold (2018) to have developed dominantly by crack-seal increments during flow of the metasediments at high strain rates on the order of $10^{-9}$ to $10^{-10} \mathrm{~s}^{-1}$. Although the shear zone itself is not interpreted to be seismically active, the high strain rates and the locally recorded high stress crystal-plastic deformation at few hundred of MPa are probably related to seismic stress pulses introduced by near-by seismic active faults in the overlying seismogenic zone (Trepmann and Seybold 2018). The deformation related to the shear zone, therefore is episodic with transient stages of flow at changing stress and strain rate conditions. The documented deformation, localized in the area at the contact between the base of the Talea Ori unit and the PQ s.str. in shear bands associated with quartz veins, is markedly different from that typically recorded from HP-LT metamorphic rocks indicating low stress deformation at HP-LT metamorphic conditions within subduction zones (Stöckhert et al. 1999; Wassmann and Stöckhert 2013). The relation of the recorded deformation to the subduction and exhumation history is discussed in the following.

\section{Shear zone development in relation to metamorphism and earlier deformation in the Talea Ori}

The extensional ductile shear zone crosscuts all earlier deformation structures in the PQ s.str. and the Talea Ori group. The albite porphyroblasts internal fabrics in the Talea Ori group and the PQ s.str. (Figs. 4d-f, 8) show that albite porphyroblast formation started overgrowing a first foliation in both units. This first foliation and early isoclinal folds most probably developed during top-to-the-south shearing (Zulauf et al. 2016), whereas the dominant foliation is related to a second deformation event with top-to-the-north shear sense at HP-LT metamorphic conditions (Zulauf et al. 2016; this study). This is consistent with the ongoing growth of albite porphyroblasts, evident by their bulging inclusion-free rims and elongation parallel to the stretching direction of the main foliation as well as by the formation of asymmetric strain shadows indicating top-to-the-north shear sense (Figs. 4e, f, 5, 8). Albite formed during Alpine metamorphism, as shown by the low $\mathrm{Pb}$ content of monazite inclusions, indicating an age younger than 60-80 Ma. This excludes a possible preAlpine origin of the monazite and the host albite porphyroblast. The observed monazite zoning with a LREE fractionation and elongation along the foliation are consistent with a metamorphic growth at (sub)greenschist-facies temperature (Janots et al. 2008). The degree of graphitization of carbonaceous material in the Talea Ori group and the PQ s.str. indicates that both units experienced the same metamorphic peak temperatures of $380-400{ }^{\circ} \mathrm{C}$ (Rahl et al. 2005; this study). These metamorphic conditions are consistent with the mineral assemblages (Seidel 1978; Seidel et al. 1982; Theye 1988; Theye and Seidel 1991; Theye et al. 1992). Overall, the Talea Ori group and the PQ s.str. show similar peak metamorphic temperatures and the same characteristics of porphyroblast growth, indicating that both units experienced a similar tectonometamorphic history (at least from the metamorphic peak temperatures). This is consistent with 
generally similar deformation history of the Talea Ori group and the PQ s.str. as described previously (Krahl et al. 1988; Chatzaras et al. 2006; Zulauf et al. 2016).

The south-vergent map-scale fold structure with E-W trending fold axis in the Talea Ori has been related by Chatzaras et al. (2006) to late compressional extrusion at high crustal levels and temperatures $<300{ }^{\circ} \mathrm{C}$. We argue, however, that this fold structure formed before the ductile deformation structures related to the extensional shear zone at the contact between PQ s.str. and Talea Ori group because of two main reasons. Firstly, the ductile shear zone crosscuts the fold structure (Fig. 1). The deflection of the dip direction of the foliation parallel to the strike of the shear zone in the east (Fig. 1), a kind of flanking structure (Mukherjee 2014b), is most probably related to the updoming of the Talea Ori group and related downfaulting of the PQ s.str. Secondly, the $\mathrm{C}^{\prime}$-type shear band cleavages and quartz veins described here developed after peak metamorphism, but still at temperatures $>300{ }^{\circ} \mathrm{C}$. They show an extensional character and-in the central Talea Ori-a top-to-the-north shear sense, which cannot be reconciled to south-vergent folding. It is likely that the south-vergent fold structure with W-E trending fold axis is related to the early nappe stacking and thrusting of the PQ s.str. onto the Talea Ori group (Chatzaras et al. 2006).

In former maps of the Talea Ori, the contact between the PQ s.str. and the Talea Ori group is displayed as thrust fault (e.g., Epting et al. 1972; Richter and Kopp 1983; Kock et al. 2007; Zulauf et al. 2016), although it is in the field rather related by steeply northward dipping normal faults (e.g., Richter and Kopp 1983). Xypolias et al. (2007) supposed that the contact between the PQ s.str. and the Talea Ori group is part of a $600 \mathrm{~km}$ long thrust-sense shear zone. The documented deformation - the extensional shear bands, $\mathrm{C}^{\prime}$-type shear band cleavage and associated quartz veinscharacterizing the contact between Talea Ori group and PQ s.str., however, gives evidence that it is related to exhumation and downfaulting of the PQ s.str.

\section{Implications for the exhumation history of the HP-LT metamorphic rocks in the Talea Ori}

The ductile extensional shear zone developed at an early stage of exhumation, close to peak metamorphic conditions, marked by high strain rate dissolution-precipitation creep of the metasediments and vein formation at temperatures higher than $300{ }^{\circ} \mathrm{C}$. The onset of exhumation was probably accompanied by seismic activity, suggested by the quartz microstructures that indicate transiently high stresses (Trepmann and Seybold 2018). Strain localized within the siliciclastic metasediments of the base of the Talea Ori group and PQ s.str., eventually resulting in the updoming of the Talea Ori group. The extensional character of the shear zone associated with vein formation suggests that the shear zone involves dilation. Normal faults overprinting the ductile shear bands at similar orientation indicate that extensional deformation in this area may have lasted during exhumation of the rocks until reaching a depth of less than $10 \mathrm{~km}$.

The degree of graphitization in the graphite schists of the Talea Ori group and the PQ s.str. did not reveal a marked temperature gradient over the extensional ductile shear zone, which might be due to the limited resolution of this technique, predicting temperatures to $\pm 50{ }^{\circ} \mathrm{C}$ (Rahl et al. 2005). However, a large temperature gradient along the shear zone within HP-LT metamorphic rocks that experienced peak temperatures of only $380-400{ }^{\circ} \mathrm{C}$ cannot be expected. Furthermore, the vertical offset might not be characterized by temperature, but rather by pressure, since the exhumation of the HP-LT metamorphic rocks was fast and close to adiabatic, with temperatures remaining higher than $300{ }^{\circ} \mathrm{C}$ up to approximately $10 \mathrm{~km}$ depth (Thomson et al. 1998). Constraints on a pressure gradient are not available. The microfabrics in both units show growth of albite during deformation at peak metamorphic conditions as well as during early stages of exhumation (Figs. 4e, f, 5a, 8) without evidence for the presence of jadeite at any stage. Thus, the vertical offset along the shear zone cannot be constrained, for which detailed data on the decompression and/or cooling path of both units would be required. For Crete, the model of syncompressional extrusion in a subduction wedge, with a basal thrust fault and an upper normal sense fault is widely accepted (e.g., Chatzaras et al. 2006; Xypolias et al. 2007; Ring et al. 2010; Jolivet et al. 2013), where strain and exhumation is supposed to be localized into the two main bounding faults (Ring and Reischmann 2002). From Western Crete dissolution-precipitation creep is found to be important during deformation at peak conditions, but evidence for deformation during exhumation was not recorded (Greiling 1982; Schwarz and Stöckhert 1996; Stöckhert et al. 1999). Our study shows that deformation during early stages of exhumation is also localized in smaller scaled shear zones and that high strain rate deformation by dissolution-precipitation creep associated with vein formation are the dominant deformation processes.

\section{Summary}

Based on the documented deformation (micro)structures characterizing the several hundred $\mathrm{m}$ up to $\mathrm{km}$ wide area at the contact between the base of the Talea Ori group and the PQ s.str. on map-scale down to the grain scale, we summarize the conclusions as follows.

- The ductile extensional shear zone is documented by extensional shear bands with boundaries dipping at 
$40-70^{\circ}$, where the hanging blocks are systematically downfaulted, $\mathrm{C}^{\prime}$-type shear band cleavages, asymmetric boudinage, foliation boudinage and associated quartz veins.

- Deformation characterizing the shear zone is by high strain rate dissolution-precipitation creep (evident by albite growth rims, mica along shear band cleavage, stylolites, strain shadows) and associated vein formation at temperatures close to peak metamorphic temperatures ( $\geq 300-350{ }^{\circ} \mathrm{C}$ ).

- The shear zone overprints the main foliation in both units. The similarities of paragenesis (albite), peak metamorphic temperatures and structural inventory in the PQ s.str. and Talea Ori group, indicate the common tectonometamorphic history.

- No change in peak metamorphic temperatures (380$400{ }^{\circ} \mathrm{C}$ ) across the shear zone is apparent by the degree of graphitization and the mineral assemblage in the graphite- and albite-bearing schists of both units.

- The vertical offset along the extensional shear zone is difficult to estimate, given the same inferred peak metamorphic temperatures for both units. Due to the fast exhumation of the rocks, temperatures higher than $300{ }^{\circ} \mathrm{C}$ were maintained during uplift up to a depth of $10 \mathrm{~km}$, and the vertical offset would be characterized rather by the pressure than by the temperature. The decompression path of the rocks would be required to give information on the amount of exhumation.

The high strain rate dissolution-precipitation creep accompanied by vein formation resulting in the extensional ductile shear zone is interpreted to mark the onset of exhumation from peak metamorphic conditions, finally resulting in the updoming of the HP-LT metamorphic rocks in the Talea Ori.

Acknowledgements This study was funded by the Deutsche Forschungsgemeinschaft (DFG Grant no. TR534/5-1). Wolfgang Dörr, Jochen Krahl, Gernold Zulauf, Bernhard Stöckhert and Jens Nüchter are gratefully acknowledged for discussions. We thank Melanie Kaliwoda for the opportunity and her support to use Raman spectroscopy and Namvar Jahanmehr, Michael Herrmann and Vladimir Ruttner for preparation of thin sections. Uwe Ring, Jeffrey Rahl and Soumyajit Mukherjee are gratefully acknowledged for constructive reviews that greatly improved the quality of the manuscript.

Open Access This article is distributed under the terms of the Creative Commons Attribution 4.0 International License (http://creativeco mmons.org/licenses/by/4.0/), which permits unrestricted use, distribution, and reproduction in any medium, provided you give appropriate credit to the original author(s) and the source, provide a link to the Creative Commons license, and indicate if changes were made.

\section{References}

Beyssac O, Goffé B, Chopin C, Rouzaud J (2002) Raman spectra of carbonaceous material in metasediments: a new geothermometer. J Metamorph Geol 20:859-871

Birtel S, Stöckhert B (2008) Quartz veins record earthquake-related brittle failure and short term ductile flow in the deep crust. Tectonophys 457:53-63

Bonneau M (1984) Correlation of the Hellenide nappes in the southeast Aegean and their tectonic reconstruction. Geol Soc London Spec Publ 17:517-527

Chatzaras V, Xypolias P, Doutsos T (2006) Exhumation of high-pressure rocks under continuous compression: a working hypothesis for the southern Hellenides (central Crete, Greece). Geol Mag 143:859-876

Creutzburg N, Seidel E (1975) Zum Stand der Geologie des Präneogens auf Kreta. N Jb Geol Palaeont Abh 198:363-383

Doutsos T, Koukouvelas I, Poulimenos G, Kokkalas S, Xypolias P, Skourlis K (2000) An exhumation model of the south Peloponnesus, Greece. Int J Earth Sci 89:350-365

Jacobshagen V, Dürr S, Kockel F, Makris J, Dornsiepen UF, Giese P, Wallbrecher E (1986) Geologie von Griechenland. Beiträge zur regionalen Geologie der Erde, Band 19. Berlin: Borntraeger, 3443110192

Epting M, Kudrass H, Leppig U, Schäfer A (1972) Geologie der Talea Ori/Kreta. N Jb Geol Palaeont Abh 141:259-285

Fassoulas C, Kilias A, Mountrakis D (1994) Postnappe stacking extension and exhumation of high-pressure/low-temperature rocks in the island of Crete. Greece Tecton 13:127-138

Feldhoff R, Lücke A, Richter D (1991) Über die Diagenese-/Metamorphosebedingungen der Pindos-und Tripolitza-Serie auf der Insel Kreta (Griechenland). Zentralbl Geol Paläontol Teil 1:1611-1622

Feldhoff R, Theye T, Richter D (1993) Coal rank versus illite crystallinity and estimated P-T conditions: some problems concerning the Pindos, Tripolitza and phyllite-quartzite series in Crete. Bull Geol Soc Greece 28:603

Greiling R (1982) The metamorphic and structural evolution of the Phyllite-Quartzite nappe of western Crete. J Struct Geol 4:291-297

Hall R, Audley-Charles M (1983) The structure and regional significance of the Talea Ori, Crete. J Struct Geol 5:167-179

Jacobshagen V, Dürr S, Kockel F, Kopp K, Kowalczyk G, Berckhemer H, Büttner D (1978) Structure and geodynamic evolution of the Aegean region. In: Alps, Apennines, Hellenides, vol 38. Schweizerbart Stuttgart, pp 455-477

Janots E, Engi M, Berger A, Allaz J, Schwarz JO, Spandler C (2008) Prograde metamorphic sequence of REE minerals in pelitic rocks of the Central Alps: implications for allanite-monazite-xenotime phase relations from 250 to 610 C. J Metamorph Geol 26:509-526

Jolivet L, Goffé B, Monié P, Truffert-Luxey C, Patriat M, Bonneau M (1996) Miocene detachment in Crete and exhumation P-T-t paths of high-pressure metamorphic rocks. Tectonics 15:1129-1153

Jolivet L et al (2013) Aegean tectonics: Strain localisation, slab tearing and trench retreat. Tectonophys 597:1-33

Kilias A, Fassoulas C, Mountrakis D (1994) Tertiary extension of continental crust and uplift of Psiloritis metamorphic core complex in the central part of the Hellenic Arc (Crete, Greece). In: Active continental margins-present and past. Springer, pp 417-430 (3662377093)

Klein T, Reichhardt H, Klinger L, Grigull S, Wostal G, Kowalczyk G, Zulauf G (2008) Reverse slip along the contact Phyllite-Quartzite Unit/Tripolitsa Unit in eastern Crete: implications for the geodynamic evolution of the External Hellenides. [Kontraktive Tektonik entlang des Kontakts von Phyllit-Quarzit-und TripolitsaEinheit in Ostkreta: Folgen für die geodynamische Entwicklung der Externen Helleniden.]. Z Dtsch Ges Geowiss 159:375-398 
Klein T, Craddock J, Zulauf G (2013) Constraints on the geodynamical evolution of Crete: insights from illite crystallinity, Raman spectroscopy and calcite twinning above and below the 'Cretan detachment'. Int J Earth Sci 102:139-182

Kock S, Martini R, Reischmann T, Stampfli G (2007) Detrital zircon and micropalaeontological ages as new constraints for the lowermost tectonic unit (Talea Ori unit) of Crete, Greece. Palaeogeogr Palaeoclimatol Palaeoecol 243:307-321

König H, Kuss S (1980) Neue Daten zur Biostratigraphie des permotriadischen Autochthons der Insel Kreta (Griechenland). N Jb Geol Palaeont Mh 9:525-540

Krahl J, Richter D, Förster O, Kozur H, Hall R (1988) Zur Stellung der Talea Ori im Bau des kretischen Deckenstapels (Griechenland). Z Dtsch Geol Ges:191-227

Kuss S, Thorbecke G (1974) Die präneogenen Gesteine der Insel Kreta und ihre Korrelierbarkeit im ägäischen Raum. Ber Naturf Ges Freiburg I Br 64:39-75

Lister GS, Banga G, Feenstra A (1984) Metamorphic core complexes of Cordilleran type in the Cyclades, Aegean Sea, Greece. Geology $12: 221-225$

Lougheed MS, Mancuso JJ (1973) Hematite framboids in the negaunee iron formation, Michigan; evidence for their Biogenic Origin. Econ Geol 68(2):202-209

Manutsoglu E, Mertmann D, Soujon A, Dornsiepen U, Jacobshagen V (1995a) Zur Nomenklatur der Metamorphite auf der Insel Kreta, Griechenland. Berliner Geowiss Abh E 16:579-588

Manutsoglu E, Soujon A, Reitner J, Dornsiepen U (1995b) Relics of lithistid demosponges from the metamorphic Plattenkalk Series of Crete island (Greece) and their paleobathymetric significance. N Jb Geol Palaeont Mh:235-235

Meier T, Becker D, Endrun B, Rische M, Bohnhoff M, Stöckhert B, Harjes H-P (2007) A model for the Hellenic subduction zone in the area of Crete based on seismological investigations. Geol Soc London Spec Publ 291:183-199

Mukherjee S (2013a) Deformation microstructures in rocks. Springer, Berlin (3642256082)

Mukherjee S (2013b) Higher Himalaya in the Bhagirathi section (NW Himalaya, India): its structures, backthrusts and extrusion mechanism by both channel flow and critical taper mechanisms. Int $\mathbf{J}$ Earth Sci 102:1851-1870

Mukherjee S (2014a) Atlas of shear zone structures in meso-scale. Springer, Berlin (3319000888)

Mukherjee S (2014b) Review of flanking structures in meso-and microscales. Geol Mag 151:957-974

Mukherjee S (2017) Review on symmetric structures in ductile shear zones. Int J Earth Sci 106:1453-1468

Papanikolaou D, Vassilakis E (2010) Thrust faults and extensional detachment faults in Cretan tectono-stratigraphy: implications for Middle Miocene extension. Tectonophys 488:233-247

Paquette J-L, Tiepolo M (2007) High resolution $(5 \mu \mathrm{m}) \mathrm{U}-\mathrm{Th}-\mathrm{Pb}$ isotope dating of monazite with excimer laser ablation (ELA)ICPMS. Chem Geol 240:222-237

Passchier CW, Trouw RA (2005) Microtectonics. vol 1. Springer Science \& Business Media, Berlin (3540293590)

Platt J, Vissers R (1980) Extensional structures in anisotropic rocks. J Struct Geol 2:397-410

Rahl JM, Anderson KM, Brandon MT, Fassoulas C (2005) Raman spectroscopic carbonaceous material thermometry of low-grade metamorphic rocks: calibration and application to tectonic exhumation in Crete, Greece. Earth Planet Sci Lett 240:339-354

Richter D, Kopp K (1983) Zur Tektonik der untersten geologischen Stockwerke auf Kreta. N Jb Geol Paläont Monatsh 1983:27-46

Ring U, Reischmann T (2002) The weak and superfast Cretan detachment, Greece: exhumation at subduction rates in extruding wedges. J Geol Soc 159:225-228
Ring U, Glodny J, Will T, Thomson S (2010) The Hellenic subduction system: high-pressure metamorphism, exhumation, normal faulting, and large-scale extension. Annu Rev Earth Planet Sci $38: 45-76$

Robertson AH (2012) Late Palaeozoic-Cenozoic tectonic development of Greece and Albania in the context of alternative reconstructions of Tethys in the Eastern Mediterranean region. Int Geol Rev 54:373-454

Robertson A et al (1996) Alternative tectonic models for the Late Palaeozoic-Early Tertiary development of Tethys in the Eastern Mediterranean region. Geol Soc London Spec Publ 105:239-263

Schwarz S, Stöckhert B (1996) Pressure solution in siliciclastic HP-LT metamorphic rocks-Constraints on the state of stress in deep levels of accretionary complexes. Tectonophys 255:203-209

Seidel E (1978) Zur Petrologie der Phyllit-Quarzit-Serie Kretas. Technische Universität, Braunschweig

Seidel E, Kreuzer H, Harre W (1982) A late Oligocene/early Miocene high pressure belt in the external Hellenides. Geol Jahrb E 23:165-206

Seidel M, Seidel E, Stöckhert B (2007) Tectono-sedimentary evolution of lower to middle Miocene half-graben basins related to an extensional detachment fault (western Crete, Greece). Terra Nova 19:39-47

Soujon A, Jacobshagen V, Manutsoglu E (1998) A lithostratigraphic correlation of the Plattenkalk occurences of Crete (Greece). Bull Geol Soc Greece 32:41-48

Stöckhert B, Wachmann M, Küster M, Bimmermann S (1999) Low effective viscosity during high pressure metamorphism due to dissolution precipitation creep: the record of HP-LT metamorphic carbonates and siliciclastic rocks from Crete. Tectonophys 303:299-319

ten Veen J, Kleinspehn K (2003) Incipient continental collision and plate-boundary curvature: Late Pliocene-Holocene transtenstional Hellenic forearc, Crete, Greece. J Geol Soc (London) 160:1-21

Theye T (1988) Aufsteigende Hochdruckmetamorphose in Sedimenten der Phyllit-Quarzit-Einheit Kretas und des Peloponnes. Technische Universität, Braunschweig

Theye T, Seidel E (1991) Petrology of low-grade high-pressure metapelites from the External Hellenides (Crete, Peloponnese) a case study with attention to sodic minerals. Eur J Miner 3:343-366

Theye T, Seidel E, Vidal O (1992) Carpholite, sudoite, and chloritoid in low-grade high-pressure metapelites from Crete and the Peloponnese, Greece. Eur J Miner 4:487-508

Thomson SN, Stöckhert B, Brix MR (1998) Thermochronology of the high-pressure metamorphic rocks of Crete, Greece: implications for the speed of tectonic processes. Geology 26:259-262

Thomson SN, Stöckhert B, Brix MR (1999) Miocene high-pressure metamorphic rocks of Crete, Greece: rapid exhumation by buoyant escape. Geol Soc London Spec Publ 154:87-107

Trepmann CA, Seybold L (2018) Deformation at low and high stress-loading rates. Geosci Front. https://doi.org/10.1016/j. gsf.2018.05.002

Wassmann S, Stöckhert B (2013) Rheology of the plate interface-dissolution precipitation creep in high pressure metamorphic rocks. Tectonophys 608:1-29

Whitney DL, Evans BW (2010) Abbreviations for names of rock-forming minerals. Am Mineral 95:185-187

Xypolias P, Chatzaras V, Koukouvelas I (2007) Strain gradients in zones of ductile thrusting: Insights from the External Hellenides. J Struct Geol 29:1522-1537

Zulauf G, Dörr W, Krahl J, Lahaye Y, Chatzaras V, Xypolias P (2016) U-Pb zircon and biostratigraphic data of high-pressure/ low-temperature metamorphic rocks of the Talea Ori: tracking the Paleotethys suture in central Crete, Greece. Int J Earth Sci 105:1901-1922 